Repassivation Potential of Alloy 22 in Sodium and Calcium Chloride Brines

Raul B. Rebak, Gabriel O. Ilevbare, Ricardo M. Carranza

August 13, 2007

Scientific Basis for Nuclear Waste Management XXXI Sheffield, United Kingdom September 16, 2007 through September 21, 2007 
This document was prepared as an account of work sponsored by an agency of the United States Government. Neither the United States Government nor the University of California nor any of their employees, makes any warranty, express or implied, or assumes any legal liability or responsibility for the accuracy, completeness, or usefulness of any information, apparatus, product, or process disclosed, or represents that its use would not infringe privately owned rights. Reference herein to any specific commercial product, process, or service by trade name, trademark, manufacturer, or otherwise, does not necessarily constitute or imply its endorsement, recommendation, or favoring by the United States Government or the University of California. The views and opinions of authors expressed herein do not necessarily state or reflect those of the United States Government or the University of California, and shall not be used for advertising or product endorsement purposes. 
Paper prepared for the proceedings of the Scientific Basis for Nuclear Waste Management XXXI Conference in Sheffield, UK, 16-21 September 2007

\title{
Repassivation Potential of Alloy 22 in Sodium and Calcium Chloride Brines
}

\author{
Raul B. Rebak, ${ }^{1}$ Gabriel O. Ilevbare ${ }^{2}$ and Ricardo M. Carranza ${ }^{3}$ \\ ${ }^{1}$ Lawrence Livermore National Laboratory, Livermore, CA 94550, USA \\ ${ }^{2}$ Electric Power Research Institute, Palo Alto, CA, 94304, USA \\ ${ }^{3}$ Atomic Energy Commission of Argentina, 1650 Buenos Aires, Argentina
}

\begin{abstract}
A comprehensive matrix of 60 tests was designed to explore the effect of calcium chloride vs. sodium chloride and the ratio $\mathrm{R}$ of nitrate concentration over chloride concentration on the repassivation potential of Alloy 22. Tests were conducted using the cyclic potentiodynamic polarization (CPP) technique at $75^{\circ} \mathrm{C}$ and at $90^{\circ} \mathrm{C}$. Results show that at a ratio $\mathrm{R}$ of 0.18 and higher nitrate was able to inhibit the crevice corrosion in Alloy 22 induced by chloride. Current results fail to show in a consistent way a different effect on the repassivation potential of Alloy 22 for calcium chloride solutions than for sodium chloride solutions.
\end{abstract}

\section{INTRODUCTION}

Alloy 22 (N06022) is a nickel base alloy especially designed to be resistant to all forms of corrosion. Alloy 22 contains approximately 56\% nickel (Ni), 22\% chromium (Cr), 13\% molybdenum (Mo), 3\% tungsten (W) and 3\% iron (Fe) (ASTM B 575). ${ }^{1}$ Because of its high level of Cr, Alloy 22 remains passive in most industrial environments and therefore has an exceptionally low general corrosion rate. ${ }^{2-6}$ Because this Alloy 22 is Ni based, it does not suffer environmentally assisted cracking in hot chloride solutions. ${ }^{3}$ The resistance of Alloy 22 to localized corrosion in chloride solutions is given by the combined presence of Cr, Mo and W. ${ }^{7-12}$ However, Alloy 22 may suffer crevice corrosion when it is anodically polarized in chloridecontaining solutions. ${ }^{8-10,13-15}$ The presence of nitrate $\left(\mathrm{NO}_{3}{ }^{-}\right)$in the solution minimizes or eliminates the susceptibility of Alloy 22 to crevice corrosion. ${ }^{8-10,16-23}$ The value of the ratio $\mathrm{R}=$ $\left[\mathrm{NO}_{3}{ }^{-}\right] /\left[\mathrm{Cl}^{-}\right]$has a strong effect of the susceptibility of Alloy 22 to crevice corrosion. ${ }^{16-25}$ The higher the nitrate to chloride ratio $\mathrm{R}$, the stronger is the inhibition by nitrate. The minimum required $\mathrm{R}$ value for inhibition may depend on other experimental variables such as total concentration of chloride and temperature. Other anions in solution were also reported to inhibit crevice corrosion in Alloy 22.

The objective of this work was to examine the susceptibility of Alloy 22 in several electrolyte solutions containing sodium chloride $(\mathrm{NaCl})$, calcium chloride $\left(\mathrm{CaCl}_{2}\right)$ and sodium nitrate $\left(\mathrm{NaNO}_{3}\right)$ using the cyclic potentiodynamic polarization (CPP) technique. ${ }^{29}$ Ratios $\mathrm{R}$ of nitrate over chloride from 0.0086 to 0.25 were investigated.

\section{EXPERIMENTAL TECHNIQUE}

Alloy 22 specimens were prepared from 1-inch thick plate. The specimens were creviced using a ceramic washer and PTFE tape. ${ }^{15,30,31}$ The specimens were multiple crevice assemblies 
(MCA) ${ }^{23}$ or lollipops. All the tested specimens had a finished grinding of abrasive paper number 600 and were degreased in acetone and treated ultrasonically for 5 minutes in de-ionized (DI) water 1 hour prior to the start of testing. Specimens were cut from as-welded (ASW) plates. The weld in the plates was produced with matching filler metal using Gas Tungsten Arc Welding (GTAW). The welded specimens were not all weld metal but contained a weld seam band across the center of the specimen, varying in width from approximately 8 to $15 \mathrm{~mm}$.

The electrochemical tests were carried out in ten different $\mathrm{NaCl}, \mathrm{CaCl}_{2}$ and $\mathrm{NaNO}_{3}$ electrolytes (Table 1). All the solutions were rather concentrated, from a little over 2 molar (M) (Electrolyte 1) to more than 6 molar (Electrolyte 10). The ratio $\mathrm{R}$ of nitrate over chloride varied from 0.0086 (Electrolyte 9) to 0.25 (Electrolyte 4). The addition of either $\mathrm{NaCl}$ or $\mathrm{CaCl}_{2}$ was used as a testing variable. For example, Electrolytes 2 and 3 have the same total chloride concentration and same ratio R; however, Electrolyte 2 was rich in $\mathrm{NaCl}$ and Electrolyte 3 was rich in $\mathrm{CaCl}_{2}$. The same is applicable for Electrolytes 5 and 6 . The $\mathrm{pH}$ of the solutions was not adjusted, and was near neutral. The testing temperatures were $75^{\circ} \mathrm{C}$ and $90^{\circ} \mathrm{C}$.

Table 1 - Matrix of electrolyte solutions

\begin{tabular}{|c|l|c|c|c|c|c|}
\hline $\begin{array}{c}\text { Electro- } \\
\text { lyte }\end{array}$ & \multicolumn{1}{|c|}{ Composition } & $\begin{array}{c}{\left[\mathrm{Cl}^{-}\right]} \\
\mathrm{NaCl}\end{array}$ & $\begin{array}{c}{\left[\mathrm{Cl}^{-}\right]} \\
\mathrm{CaCl}_{2}\end{array}$ & $\begin{array}{c}\text { Total } \\
{\left[\mathrm{Cl}^{-}\right]}\end{array}$ & {$\left[\mathrm{NO}_{3}^{-}\right]$} & $\begin{array}{c}\mathrm{R}= \\
{\left[\mathrm{NO}_{3}\right] /[\mathrm{Cl}]}\end{array}$ \\
\hline & & & & & & \\
\hline 1 & $1 \mathrm{M} \mathrm{NaCl}+0.5 \mathrm{M} \mathrm{CaCl}_{2}+0.05 \mathrm{M} \mathrm{NaNO}_{3}$ & 1 & 1 & 2 & 0.05 & 0.025 \\
\hline 2 & $4 \mathrm{M} \mathrm{NaCl}+0.5 \mathrm{M} \mathrm{CaCl}_{2}+0.05 \mathrm{M} \mathrm{NaNO}_{3}$ & 4 & 1 & 5 & 0.05 & 0.01 \\
\hline 3 & $1 \mathrm{M} \mathrm{NaCl}+2 \mathrm{M} \mathrm{CaCl}_{2}+0.05 \mathrm{M} \mathrm{NaNO}_{3}$ & 1 & 4 & 5 & 0.05 & 0.01 \\
\hline 4 & $1 \mathrm{M} \mathrm{NaCl}+0.5 \mathrm{M} \mathrm{CaCl}_{2}+0.5 \mathrm{M} \mathrm{NaNO}_{3}$ & 1 & 1 & 2 & 0.5 & 0.25 \\
\hline 5 & $1 \mathrm{M} \mathrm{NaCl}+2 \mathrm{M} \mathrm{CaCl}_{2}+0.5 \mathrm{M} \mathrm{NaNO}_{3}$ & 1 & 4 & 5 & 0.5 & 0.1 \\
\hline 6 & $4 \mathrm{M} \mathrm{NaCl}+0.5 \mathrm{M} \mathrm{CaCl}_{2}+0.5 \mathrm{M} \mathrm{NaNO}_{3}$ & 4 & 1 & 5 & 0.5 & 0.1 \\
\hline 7 & $1.8 \mathrm{M} \mathrm{NaCl}+0.5 \mathrm{M} \mathrm{CaCl}_{2}+0.05 \mathrm{M} \mathrm{NaNO}_{3}$ & 1.8 & 1 & 2.8 & 0.05 & 0.018 \\
\hline 8 & $1.8 \mathrm{M} \mathrm{NaCl}+0.5 \mathrm{M} \mathrm{CaCl}_{2}+0.5 \mathrm{M} \mathrm{NaNO}_{3}$ & 1.8 & 1 & 2.8 & 0.5 & 0.18 \\
\hline 9 & $1.8 \mathrm{M} \mathrm{NaCl}+2 \mathrm{M} \mathrm{CaCl}_{2}+0.05 \mathrm{M} \mathrm{NaNO}_{3}$ & 1.8 & 4 & 5.8 & 0.05 & 0.0086 \\
\hline 10 & $1.8 \mathrm{M} \mathrm{NaCl}+2 \mathrm{M} \mathrm{CaCl}_{2}+0.5 \mathrm{M} \mathrm{NaNO}_{3}$ & 1.8 & 4 & 5.8 & 0.5 & 0.086 \\
\hline & & & & & & \\
\hline
\end{tabular}

The electrochemical tests were conducted in a one-liter, three-electrode, borosilicate glass flask (ASTM G5). ${ }^{29}$ A water-cooled condenser combined with a water trap was used to avoid evaporation of the solution and to prevent the ingress of air (oxygen). All the tests were carried out at ambient pressure. The reference electrode was saturated silver chloride (SSC), which at ambient temperature has a potential of $199 \mathrm{mV}$ more positive than the standard hydrogen electrode (SHE). The reference electrode was connected to the solution through a water-jacketed Luggin probe so that the electrode was maintained at near ambient temperature. The counter electrode was a flag $\left(36 \mathrm{~cm}^{2}\right)$ of platinum foil spot-welded to a platinum wire. All the potentials in this paper are reported in the SSC scale. Nitrogen $\left(\mathrm{N}_{2}\right)$ was purged through the solution at a flow rate of $100 \mathrm{cc} / \mathrm{min}$ for 24 hours while the corrosion potential $\left(\mathrm{E}_{\text {corr }}\right)$ was monitored. Nitrogen bubbling was continued throughout all the electrochemical tests. The specimens were immersed for 24 hours in the deaerated electrolytes at temperature while nitrogen gas was purged through the solution. The open circuit potential of the working electrodes were recorded during the 24-hr immersion and the value at the end of the 24-hr immersion was called the corrosion potential ( $\mathrm{E}_{\text {corr }}$-24hr). After the 24-hour immersion, a cyclic potentiodynamic polarization (CPP) was performed. In the CPP tests, the potential scan was started approximately $100 \mathrm{mV}$ below $\mathrm{E}_{\text {corr }}$ at a set scan rate of $0.167 \mathrm{mV} / \mathrm{s}$. The scan direction was generally reversed when the current 
density reached $30 \mathrm{~mA} / \mathrm{cm}^{2}$ in the forward scan. The total applied current density was higher than the recommended by the ASTM standard G 61 of $5 \mathrm{~mA} / \mathrm{cm}^{2}$. The CPP test is a fast and efficient method to determine crevice corrosion resistance of commercial alloys. In the forward scan of the CPP, the potentials for which the current density is 20 and $200 \mu \mathrm{A} / \mathrm{cm}^{2}$ are called E20 and E200. 9,18,21,31 These parameters represent values of breakdown potentials. In the reverse scan of the CPP, the values of potentials for which the current density is 10 and $1 \mu \mathrm{A} / \mathrm{cm}^{2}$ are called ER10 and ER1. The potential at which the reverse scan intersects the forward scan is called repassivation potential cross over (ERCO). ER10, ER1 and ERCO represent values of repassivation potentials.

After the CPP and THE tests, the specimens were examined in an optical stereomicroscope at a magnification of 20 times to establish the mode and location of the attack.

\section{RESULTS}

\section{Cyclic potentiodynamic polarization (CPP)}

Figure 1 shows the CPP curves for specimens JE1733 and JE1707 tested in Electrolyte 2 ( $\mathrm{NaCl}$ dominated) at $75^{\circ} \mathrm{C}$ and $90^{\circ} \mathrm{C}$. The passive current density for both specimens was practically the same. The range of passivity was wide (higher than $700 \mathrm{mV}$ ). The breakdown potential at $75^{\circ} \mathrm{C}$ was slightly higher than at $90^{\circ} \mathrm{C}$. Table 2 shows that E20 for JE1733 was +488 $\mathrm{mV}$ SSC while the E20 for JE1707 was $+304 \mathrm{mV}$ SSC. Both specimens suffered a significant hysteresis in the return scan suggesting the presence of crevice corrosion. The repassivation potential ER1 was practically the same for both specimens (ER1 was $-111 \mathrm{mV}$ SSC for JE1733 and $-100 \mathrm{mV}$ SSC for JE1707) (Table 2 and Figure 1). The repassivation potential was even slightly lower in the lower temperature solution. This could be an artifact of the test method and related to diffusion processes. If the scan rate is decreased ten times or the Tsujikawa-Hisamatsu method is used, it is likely that the trend between ER1 vs. temperature may disappear or even reverse itself. Electrolyte 2 is a high chloride low nitrate solution $(\mathrm{R}=0.01)$ and therefore it is assumed that Alloy 22 would suffer crevice corrosion for the high applied potentials at the tested temperatures (Figure 1). Table 2 shows that both of these specimens suffered crevice corrosion as well as abundant transpassivity due to the high final applied current density of $30 \mathrm{~mA} / \mathrm{cm}^{2}$.

Figure 2 shows information similar to Figure 1 but for a $\mathrm{CaCl}_{2}$ dominated solution (Electrolyte 3). The same discussion above for Figure 1 can be applied to discuss Figure 2. The repassivation potential ER1 was lower for JE1720 tested at $75^{\circ} \mathrm{C}$ (ER1 $=-105 \mathrm{mV} \mathrm{SSC}$ ) than for $\mathrm{JE} 1722$ tested at $90^{\circ} \mathrm{C}(\mathrm{ER} 1=-80 \mathrm{mV} \mathrm{SSC})$. Analyses of Figures 1 and 2 seem to suggest that $\mathrm{NaCl}$ rich solutions yielded slightly lower repassivation potentials than the $\mathrm{CaCl}_{2}$ rich solutions.

Figure 3 shows comparatively the behavior of Alloy 22 in the $\mathrm{NaCl}$ rich and $\mathrm{CaCl}_{2}$ rich electrolytes (Electrolytes 2 and 3) for solutions with $\mathrm{R}=0.01$ at $90^{\circ} \mathrm{C}$. Figure 3 shows that under the tested conditions Alloy 22 had practically the same behavior in both electrolytes, showing little or no influence of the cations in the solution. Figure 4 shows the effect of nitrate in the solution (comparing electrolytes 7 and 8). For the lower $\mathrm{R}$ value of 0.018 there was a noticeable hysteresis in the reverse scan suggesting the presence of crevice corrosion; however, when $\mathrm{R}=$ 0.18 , there was no reverse scan hysteresis. Table 2 shows that crevice corrosion was observed in specimen JE1758 $(\mathrm{R}=0.018)$; but in specimen JE1766 only transpassive dissolution was present after the CPP tests. Results from Figure 4 show that for a ratio $\mathrm{R}=0.18$ at $75^{\circ} \mathrm{C}$ crevice corrosion was fully inhibited by nitrate. Similar findings have been reported before. ${ }^{8-10,16-23}$ 


\section{Crevice Repassivation Potential}

Figure 5 shows the crevice repassivation potential (ERCO) of Alloy 22 as a function of the temperature in $\mathrm{NaCl}$ and $\mathrm{CaCl}_{2}$ rich electrolytes (Electrolytes 5 and 6 ) for solutions with $\mathrm{R}=0.1$. For both solutions the ERCO decreased as the temperature increased, and, at each temperature the ERCO was lower in the $\mathrm{CaCl}_{2}$ rich solution than in the $\mathrm{NaCl}$ rich solution. An analysis of the data in Table 2 shows that this trend on the effect of the cation is not clear or even opposite in Electrolytes 2 and 3 where $\mathrm{R}=0.01$ (Figure 3 ). More systematic studies are needed to explore the effect of the cation on the repassivation potential of Alloy 22.

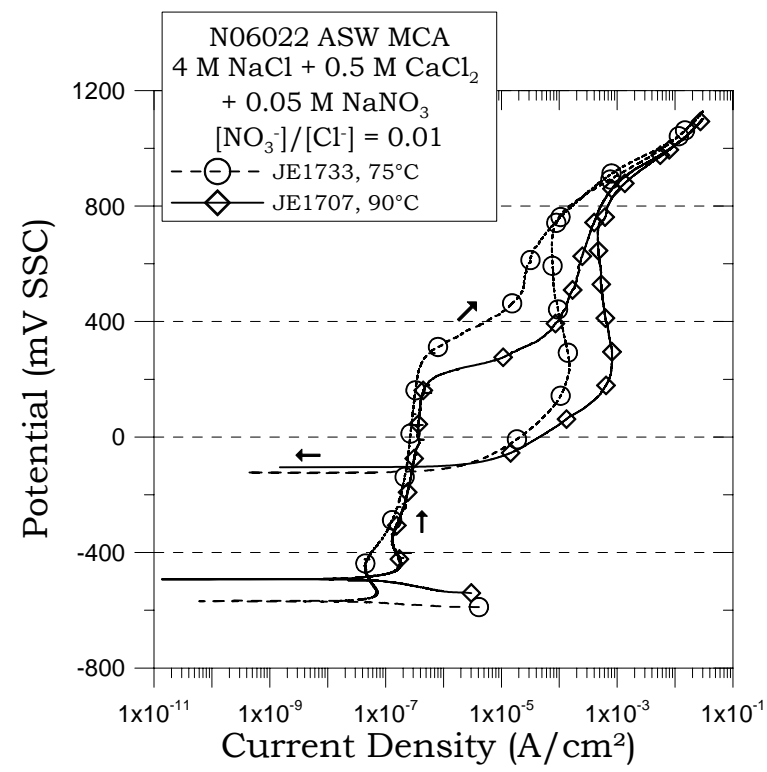

Figure 1 - Cyclic potentiodynamic polarization (CPP) in Electrolyte 2, $\mathrm{R}=0.01$

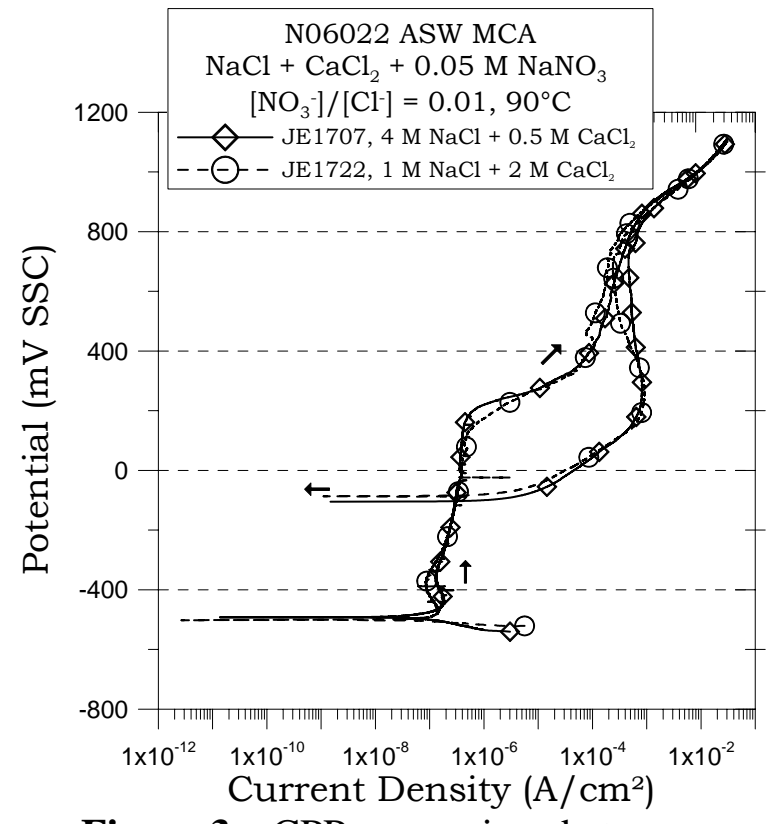

Figure 3 - CPP comparison between Electrolytes 2 and 3 at $90^{\circ} \mathrm{C}, \mathrm{R}=0.01$

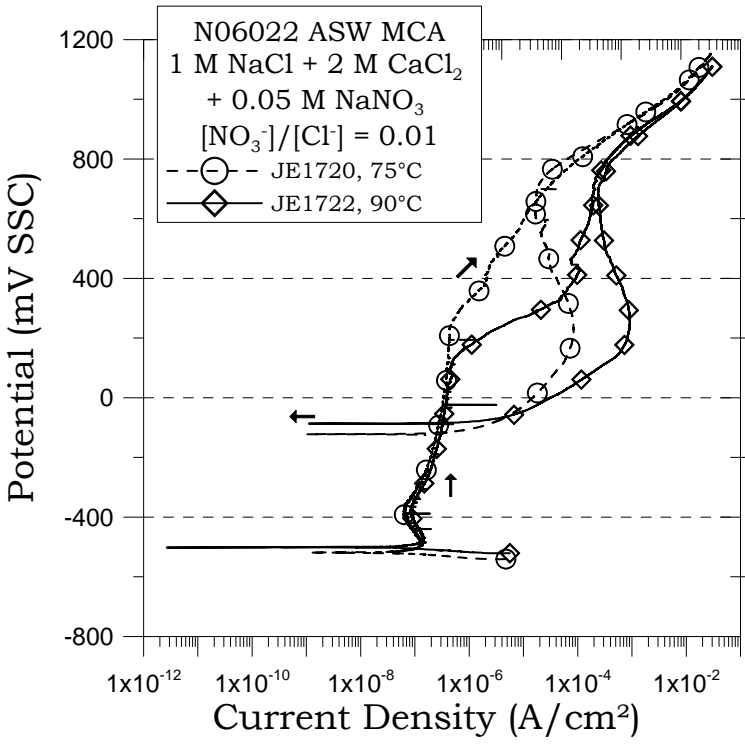

Figure 2 - Cyclic potentiodynamic polarization (CPP) in Electrolyte 3, $\mathrm{R}=0.01$

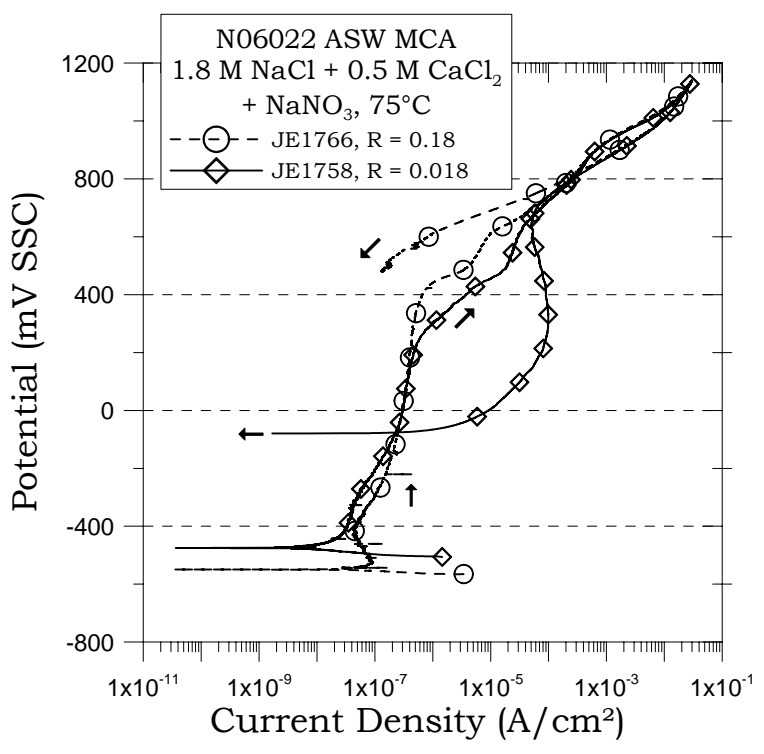

Figure 4-CPP in Electrolytes 7 and 8 at $90^{\circ} \mathrm{C}$. Effect of nitrate 
Table 2 - Parameters from the CPP Tests. All potentials are in mV SSC All the specimens suffered transpassive dissolution after the CPP tests

\begin{tabular}{|c|c|c|c|c|c|c|c|c|c|}
\hline $\begin{array}{l}\text { Electro- } \\
\text { lyte }\end{array}$ & $\mathrm{T},{ }^{\circ} \mathrm{C}$ & Specimen & $\mathrm{E}_{\text {corr }}$ & E20 & E200 & ER10 & ER1 & ERCO & Attack \\
\hline 1 & 75 & JE1723 & -478 & 540 & 791 & 33 & -69 & -82 & $\mathrm{CC}$ \\
\hline 1 & 75 & JE1721 & -486 & 723 & 785 & 24 & -60 & -71 & CC \\
\hline 1 & 75 & JE1725 & -354 & 493 & 739 & 25 & -54 & -62 & CC \\
\hline 1 & & JE1711 & -464 & 373 & 609 & -21 & -69 & -72 & $\mathrm{CC}$ \\
\hline 1 & 90 & JE1702 & -478 & 299 & 565 & -34 & -79 & -83 & CC \\
\hline 1 & 90 & JE1728 & -456 & 467 & 682 & -20 & -66 & -68 & CC \\
\hline & & & & & & & & & \\
\hline 2 & 75 & JE1730 & -490 & 609 & 836 & -38 & -111 & -123 & $\mathrm{CC}$ \\
\hline 2 & 75 & JE1705 & -461 & 282 & 620 & -34 & -80 & $\begin{array}{l}-84 \\
\end{array}$ & CC \\
\hline 2 & 75 & JE1733 & -489 & 488 & 815 & -42 & -111 & -121 & CC \\
\hline 2 & 90 & JE1718 & -487 & 199 & 296 & -50 & -73 & -75 & CC \\
\hline 2 & 90 & JE1707 & -447 & 304 & 540 & -67 & -100 & -103 & CC \\
\hline 2 & 90 & JE1729 & -489 & 200 & 293 & -58 & -100 & -104 & CC \\
\hline & & & & & & & & & \\
\hline 3 & 75 & JE1727 & -402 & 680 & 833 & -22 & -97 & -106 & CC \\
\hline 3 & 75 & JE1717 & -430 & 337 & 801 & -50 & -104 & -110 & $\mathrm{CC}$ \\
\hline 3 & 75 & JE1720 & -442 & 674 & 838 & -27 & -105 & -117 & CC \\
\hline 3 & 90 & JE1722 & -440 & 294 & 716 & -45 & -80 & -84 & CC \\
\hline 3 & 90 & JE1712 & -462 & 303 & 379 & 0 & -15 & -15 & CC \\
\hline 3 & 90 & JE1714 & -438 & 235 & 301 & -18 & -33 & -35 & CC \\
\hline & & & & & & & & & \\
\hline 4 & 75 & JE1706 & -411 & 689 & 766 & 672 & 586 & 643 & No CC \\
\hline 4 & 75 & JE1735 & -446 & 646 & 776 & 684 & 609 & 805 & No CC \\
\hline 4 & 75 & JE1724 & -438 & 620 & 758 & 686 & 611 & 831 & No CC \\
\hline & & & & & & & & & \\
\hline 4 & 90 & JE1704 & -449 & 670 & 757 & 602 & 480 & 592 & No CC \\
\hline 4 & 90 & JE1726 & -386 & 512 & 712 & 620 & 517 & 819 & No CC \\
\hline 4 & 90 & JE1734 & -475 & 613 & 722 & 621 & 444 & 218 & No CC \\
\hline & & & & & & & & & \\
\hline 5 & 75 & JE1709 & -398 & 714 & 840 & 145 & -41 & -62 & CC-II \\
\hline 5 & 75 & JE1732 & -435 & 686 & 831 & 120 & -51 & -70 & CC-II \\
\hline 5 & 75 & JE1719 & -430 & 701 & 845 & 738 & -43 & -66 & CC-II \\
\hline & & & & & & & & & \\
\hline 5 & 90 & JE1715 & -430 & 516 & 793 & -55 & -101 & -104 & $\mathrm{CC}$ \\
\hline 5 & 90 & JE1713 & -434 & 606 & 790 & -40 & -88 & -93 & CC-II \\
\hline 5 & 90 & JE1701 & -394 & 572 & 797 & -43 & -95 & -101 & CC \\
\hline & & & & & & & & & \\
\hline 6 & 75 & JE1736 & -474 & 651 & 821 & 689 & -46 & -70 & CC-II \\
\hline 6 & 75 & JE1703 & -417 & 709 & 833 & 131 & -40 & -60 & CC-II \\
\hline 6 & 75 & JE1716 & -488 & 676 & 830 & 734 & 54 & -2 & CC-II \\
\hline 6 & 90 & JE1731 & -477 & 541 & 781 & -26 & -86 & -94 & CC \\
\hline 6 & 90 & JE1710 & $\begin{array}{l}-489 \\
\end{array}$ & $\begin{array}{l}674 \\
\end{array}$ & 782 & 55 & -68 & -81 & CC-II \\
\hline 6 & 90 & JE1708 & -470 & 561 & 784 & -14 & -79 & -87 & CC \\
\hline & & & & & & & & & \\
\hline 7 & 75 & JE1740 & -483 & & & & & & N/A \\
\hline 7 & 75 & JE1758 & -406 & 511 & 775 & 5 & -66 & -76 & CC \\
\hline
\end{tabular}




\begin{tabular}{|c|c|c|c|c|c|c|c|c|c|}
\hline 7 & 75 & JE1762 & -514 & 577 & 767 & 78 & -35 & -51 & CC \\
\hline 7 & 75 & JE1767 & -359 & 532 & 787 & 22 & -70 & -87 & CC \\
\hline & & & & & & & & & \\
\hline 7 & 90 & JE1742 & -405 & & & & & & N/A \\
\hline 7 & 90 & JE1750 & -505 & 418 & 683 & -29 & -94 & -101 & CC \\
\hline 7 & 90 & JE1755 & -509 & 416 & 659 & -46 & -92 & -96 & CC \\
\hline 7 & 90 & JE1768 & -514 & 441 & 705 & -25 & -91 & -97 & CC \\
\hline & & & & & & & & & \\
\hline 8 & 75 & JE1739 & -447 & & & & & & N/A \\
\hline 8 & 75 & JE1754 & -491 & 584 & 772 & 682 & 600 & 825 & No CC \\
\hline 8 & 75 & JE1764 & -471 & 637 & 795 & 694 & 620 & 813 & No CC \\
\hline 8 & 75 & JE1766 & -480 & 644 & 787 & 690 & 612 & 818 & No CC \\
\hline & & & & & & & & & \\
\hline 8 & 90 & JE1746 & -471 & 476 & 735 & 613 & -16 & -33 & CC-II \\
\hline 8 & 90 & JE1748 & -469 & 477 & 727 & 620 & 87 & 47 & No CC \\
\hline 8 & 90 & JE1759 & -482 & 555 & 745 & 635 & 526 & 192 & No CC \\
\hline & & & & & & & & & \\
\hline 9 & 75 & JE1743 & -434 & 157 & 737 & -41 & -91 & -94 & CC \\
\hline 9 & 75 & JE1751 & -454 & 683 & 844 & -37 & -113 & -125 & CC \\
\hline 9 & 75 & JE1760 & -444 & 673 & 840 & 10 & -83 & -99 & CC \\
\hline & & & & & & & & & \\
\hline 9 & 90 & JE1737 & -432 & & & & & & N/A \\
\hline 9 & 90 & JE1749 & -494 & 481 & 781 & -72 & -107 & -110 & CC \\
\hline 9 & 90 & JE1761 & -462 & 238 & 357 & -53 & -76 & -78 & CC \\
\hline 9 & 90 & JE1765 & -476 & 256 & 336 & -37 & -62 & -64 & CC \\
\hline & & & & & & & & & \\
\hline 10 & 75 & JE1747 & -426 & 526 & 840 & 29 & -67 & -78 & CC-II \\
\hline 10 & 75 & JE1756 & -398 & 714 & 859 & 89 & -61 & -78 & CC-II \\
\hline 10 & 75 & JE1757 & -445 & 703 & 845 & 738 & 41 & -12 & No CC \\
\hline & & & & & & & & & \\
\hline 10 & 90 & JE1752 & -444 & 604 & 803 & -15 & -89 & -99 & CC-II \\
\hline 10 & 90 & JE1753 & -452 & 615 & 818 & -7 & -88 & -98 & CC \\
\hline 10 & 90 & JE1763 & -420 & 424 & 769 & -28 & -73 & -78 & CC \\
\hline & & & & & & & & & \\
\hline
\end{tabular}

Figure 6 shows the repassivation potential ER1 as a function of $\mathrm{R}$ for all the solutions in Table 2. For R between 0.0086 and 0.1 , the values of ER1 were low, near $0 \mathrm{mV}$ or below. All the specimens tested under these conditions suffered crevice corrosion (Table 2). For the specimens tested in the solutions with $\mathrm{R}=0.086$ and 0.1 , it appears that the ER1 values at $75^{\circ} \mathrm{C}$ were slightly higher than at $90^{\circ} \mathrm{C}$, confirming that a higher temperature generally produces lower repassivation potentials for some electrolyte solutions. For the electrolyte with $\mathrm{R}=0.18$, there was a separation of the behavior of the alloy at $75^{\circ} \mathrm{C}$ and $90^{\circ} \mathrm{C}$. The alloy had higher values of ER1 at $75^{\circ} \mathrm{C}$, while there was a large scattering for the values of ER1 measured at $90^{\circ} \mathrm{C}$. Finally for $\mathrm{R}=0.25$, ER1 was higher than $400 \mathrm{mV}$ at both tested temperatures.

\section{Corrosion Mode in the Tested Specimens}

Figure 7 shows crevice corrosion and transpassivity in specimen JE1714 tested in the low R Electrolyte 3 solution at $90^{\circ} \mathrm{C}$. Figure 8 shows only transpassivity in specimen JE1734 tested in Electrolyte 4 . Because of the value R of 0.25 , specimen JE1734 suffered only transpassive dissolution in spite of the high anodic potentials applied during the test. 


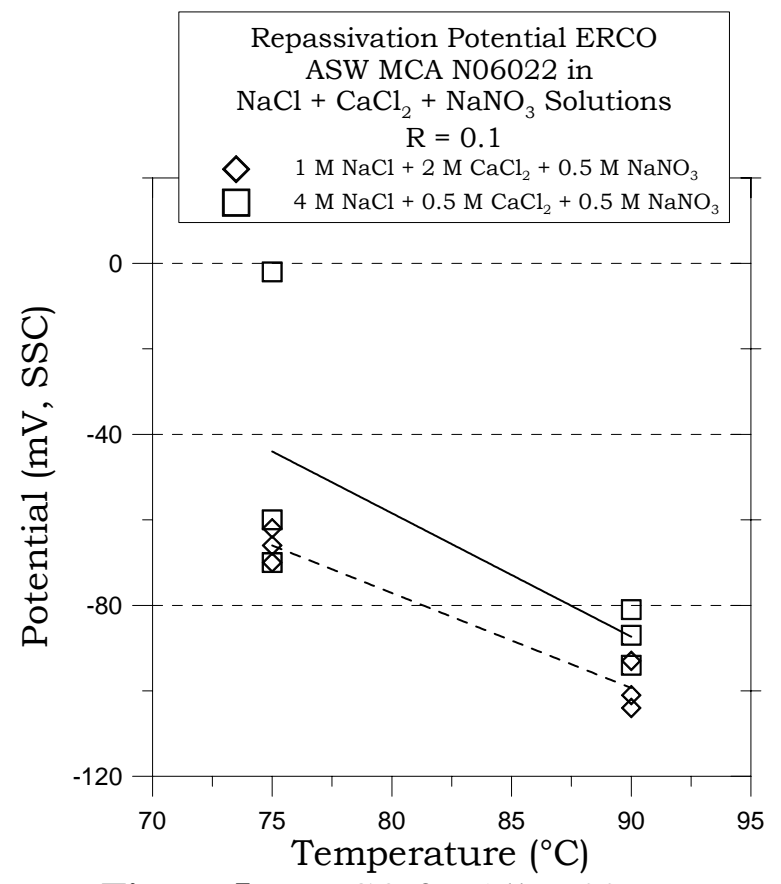

Figure 5 - ERCO for Alloy 22 vs. temperature. Effect of $\mathrm{NaCl}$ vs. $\mathrm{CaCl}_{2}$

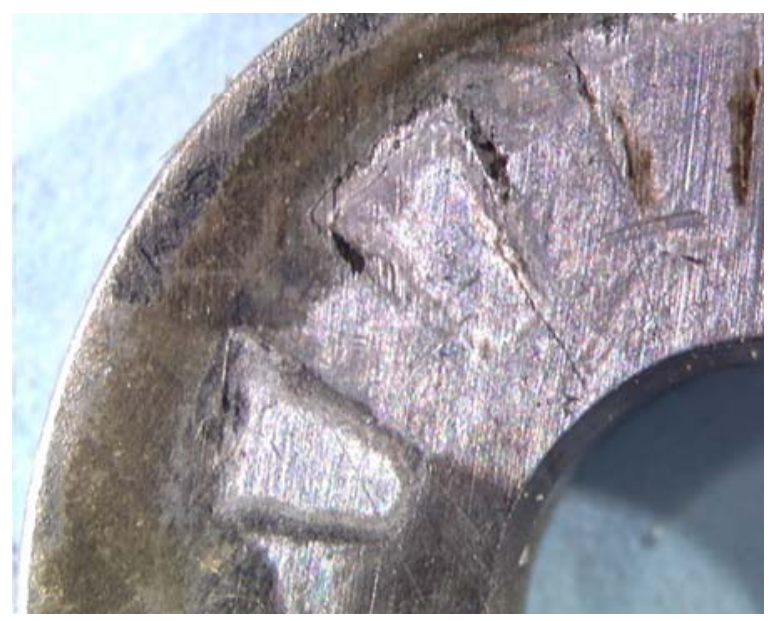

Figure 7- Specimen JE1714 after CPP in Electrolyte 3, $\mathrm{R}=0.01$ at $90^{\circ} \mathrm{C}$. Crevice corrosion and transpassivity are observed.

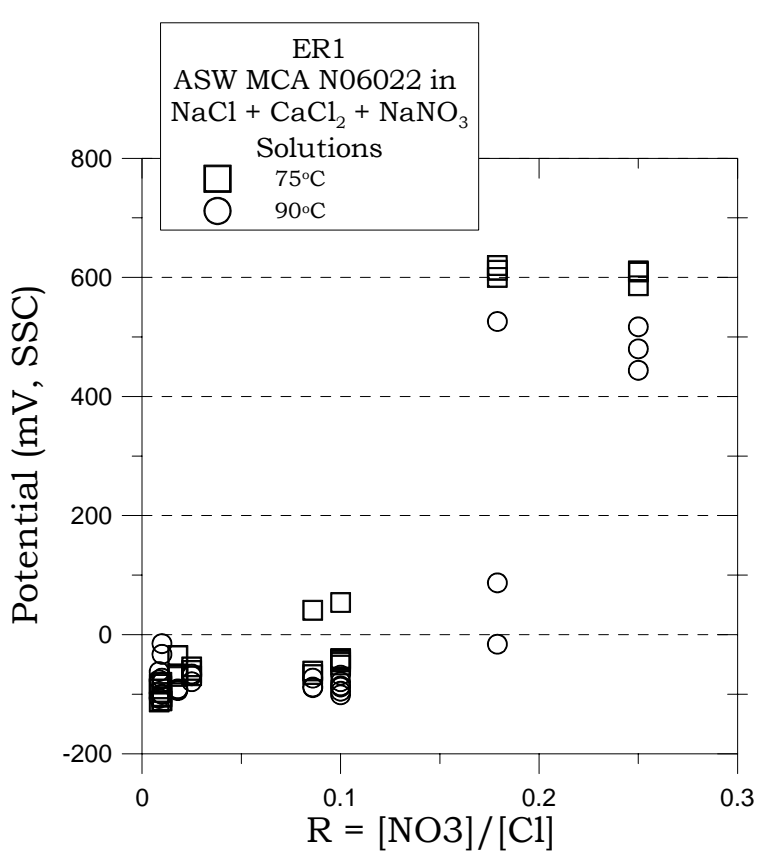

Figure 6 - ER1 for all the tests vs. ratio R

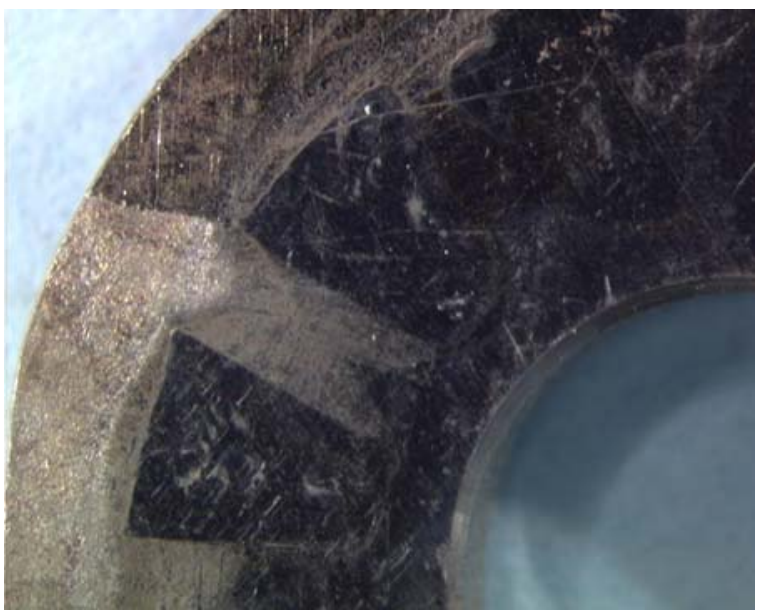

Figure 8- Specimen JE1734 after CPP in Electrolyte $4, \mathrm{R}=0.25$ at $90^{\circ} \mathrm{C}$. Only transpassivity is observed.

\section{SUMMARY}

1. It was confirmed that Alloy 22 suffers crevice corrosion when polarized in solutions that have a low ratio $\mathrm{R}$ of nitrate concentration over chloride concentration

2. When the ratio $\mathrm{R}$ was higher than 0.18 , inhibition of crevice corrosion was observed in spite of the high base concentration of chloride.

3. Studies of the effect of Ca vs. Na are not definitive. While in the $\mathrm{R}=0.1$ electrolytes $\mathrm{Ca}$ seemed more detrimental than $\mathrm{Na}$, the same trend was not evident for $\mathrm{R}=0.01$ solutions. 


\section{ACKNOWLEDGMENTS}

This work was performed under the auspices of the U. S. Department of Energy by the University of California Lawrence Livermore National Laboratory under contract No. W-7405Eng-48. The work was supported by the Yucca Mountain Project, which is part of the DOE Office of Civilian Radioactive Waste Management (OCRWM)

\section{DISCLAIMER}

This document was prepared as an account of work sponsored by an agency of the United States Government. Neither the United States Government nor the University of California nor any of their employees, makes any warranty, express or implied, or assumes any legal liability or responsibility for the accuracy, completeness, or usefulness of any information, apparatus, product, or process disclosed, or represents that its use would not infringe privately owned rights. Reference herein to any specific commercial product, process, or service by trade name, trademark, manufacturer, or otherwise, does not necessarily constitute or imply its endorsement, recommendation, or favoring by the United States Government or the University of California. The views and opinions of authors expressed herein do not necessarily state or reflect those of the United States Government or the University of California, and shall not be used for advertising or product endorsement purposes.

\section{REFERENCES}

1 ASTM International, Standard B575, Vol. 02.04 (ASTM, 2002: West Conshohocken, PA).

2 Haynes International, "Hastelloy C-22 Alloy”, Brochure H-2019E (Haynes International, 1997: Kokomo, IN).

3 R. B. Rebak in Corrosion and Environmental Degradation, Volume II, p. 69, Wiley-VCH, Weinheim, Germany (2000).

4 R. B. Rebak and P. Crook, "Nickel Alloys for Corrosive Environments," Advanced Mater. \& Proc., 157, 37, 2000.

5 R. B. Rebak and P. Crook, "Influence of the Environment on the General Corrosion Rate of Alloy 22,” PVP-Vol. 483 pp. 131-136 (ASME, 2004: New York, NY).

6 R. B. Rebak and Joe H. Payer, "Passive Corrosion Behavior of Alloy 22," ANS Conf. International High Level Radioactive Waste Management, Las Vegas 30Apr-04May 2006.

7 R. B. Rebak and P. Crook, "Improved Pitting and Crevice Corrosion Resistance of Nickel and Cobalt Based Alloys,” ECPV 98-17, pp. 289-302 (The Electrochemical Society, 1999: Pennington York, NJ).

8 B. A. Kehler, G. O. Ilevbare and J. R. Scully, Corrosion, 1042 (2001).

9 K. J. Evans and R. B. Rebak in Corrosion Science - A Retrospective and Current Status in Honor of Robert P. Frankenthal, PV 2002-13, p. 344-354 (The Electrochemical Society, 2002: Pennington, NJ).

10 K. J. Evans, S. D. Day, G. O. Ilevbare, M. T. Whalen, K. J. King, G. A. Hust, L. L. Wong, J. C. Estill and R. B. Rebak, PVP-Vol. 467, Transportation, Storage and Disposal of Radioactive Materials - 2003, p. 55 (ASME, 2003: New York, NY).

11 Y-M. Pan, D. S. Dunn and G. A. Cragnolino in Environmentally Assisted Cracking: Predictive Methods for Risk Assessment and Evaluation of Materials, Equipment and Structures, STP 1401, pp. 273-288 (West Conshohocken, PA: ASTM 2000). 
12 R. B. Rebak in Environmentally Assisted Cracking: Predictive Methods for Risk Assessment and Evaluation of Materials, Equipment and Structures, STP 1401, pp. 289-300 (West Conshohocken, PA: ASTM 2000).

13 C. S. Brossia, L. Browning, D. S. Dunn, O. C. Moghissi, O. Pensado and L. Yang, "Effect of Environment on the Corrosion of Waste Package and Drip Shield Materials," Publication of the Center for Nuclear Waste Regulatory Analyses (CNWRA 2001-03), September 2001.

14 D. S. Dunn, L. Yang, Y.-M. Pan and G. A. Cragnolino, "Localized Corrosion Susceptibility of Alloy 22,” Paper 03697 (NACE International, 2003: Houston, TX).

15 K. J. Evans, A. Yilmaz, S. D. Day, L. L. Wong, J. C. Estill and R. B. Rebak, “Comparison of Electrochemical Methods to Determine Crevice Corrosion Repassivation Potential of Alloy 22 in Chloride Solutions,” JOM, p. 56, January 2005.

16 G. A. Cragnolino, D. S. Dunn and Y.-M. Pan, "Localized Corrosion Susceptibility of Alloy 22 as a Waste Package Container Material,” Scientific Basis for Nuclear Waste Management XXV, Vol. 713 (Materials Research Society 2002: Warrendale, PA).

17 D. S. Dunn and C. S. Brossia, "Assessment of Passive and Localized Corrosion Processes for Alloy 22 as a High-Level Nuclear Waste Container Material," Paper 02548 (NACE International, 2002: Houston, TX).

18 J. H. Lee, T. Summers and R. B. Rebak, “A Performance Assessment Model for Localized Corrosion Susceptibility of Alloy 22 in Chloride Containing Brines for High Level Nuclear Waste Disposal Container,” Paper 04692 (NACE International, 2004: Houston, TX).

19 D. S. Dunn, L. Yang, C. Wu and G. A. Cragnolino, Material Research Society Symposium, Spring 2004, San Francisco, Proc. Vol. 824 (MRS, 2004: Warrendale, PA).

20 D. S. Dunn, Y.-M. Pan, L. Yang and G. A Cragnolino and X. He, "Localized Corrosion Resistance and Mechanical Properties of Alloy 22 Waste Package Outer Containers” JOM, January 2005, pp 49-55.

21 R. B. Rebak, "Factors Affecting the Crevice Corrosion Susceptibility of Alloy 22," Paper 05610, Corrosion/2005 (NACE International, 2005: Houston, TX).

22 D. S. Dunn, Y.-M. Pan, L. Yang and G. A Cragnolino, Corrosion, 61, 11, 1076, 2005.

23 G. O. Ilevbare, K. J. King, S. R. Gordon, H. A. Elayat, G. E. Gdowski and T. S. E. Gdowski, Journal of The Electrochemical Society, 152, 12, B547-B554, 2005.

24 D. S. Dunn, Y.-M. Pan, L. Yang and G. A. Cragnolino, Corrosion, 61, 1078 (2005).

25 D. S. Dunn, Y.-M. Pan, L. Yang and G. A. Cragnolino, Corrosion, 62, 3 (2006).

26 G. O. Ilevbare, Corrosion, 62, 340 (2006).

27 R. M. Carranza, M. A. Rodriguez and R. B. Rebak, "Inhibition of Chloride Induced Crevice Corrosion in Alloy 22 by Fluoride Ions,” Paper 06622, Corrosion/2006, NACE International, March 12-16, 2006, San Diego, CA (NACE International, Houston, TX).

28 R. B. Rebak, "Mechanisms of Inhibition of Crevice Corrosion in Alloy 22," in proceedings of Scientific Basis for Nuclear Waste Management XXX, (MRS, 2006: Warrendale, PA).

29 ASTM International, Volume 03.02 "Wear and Erosion; Metal Corrosion" (ASTM International, 2003: West Conshohocken, PA).

30 K. J. Evans, L. L. Wong and R. B. Rebak "Determination of the Crevice Repassivation Potential of Alloy 22 by a Potentiodynamic-Galvanostatic-Potentiostatic Method," PVPASME Vol. 483, pp. 137-149 (American Society of Mechanical Engineers, 2004: New York, NY).

31 K. J. Evans and R. B. Rebak "Determination of the Crevice Repassivation Potential of Alloy 22 by a Potentiodynamic-Galvanostatic-Potentiostatic Method," (to be published in JAI, the journal or ASTM International). 